\title{
CANA, LABOR E ADOECIMENTO: A AFIRMAÇÃO DO NEXO CAUSAL COMO UMA FORMA DE RESISTÊNCIA ${ }^{1}$ SUGAR CANE, WORK AND ILLNESS: THE AFFIRMATION OF THE CAUSATION NEXUS AS A FORM OF RESISTANCE
}

Lúcio Vasconcellos de Verçoza* Maria Aparecida de Moraes Silva**

RESUMO: O presente texto visa ao estudo das condições de trabalho e saúde vis-à-vis o momento atual da agroindústria canavieira alagoana, caracterizado pela reestruturação produtiva e pela intensificação do trabalho no corte manual da cana-de-açúcar. O aumento do esforço exigido nessa atividade laboral produz, além do sofrimento físico, o sofrimento moral e psíquico. O objetivo principal deste artigo é contribuir para as reflexões acerca do nexo causal entre o adoecimento e o trabalho do corte da cana. Para atingir tal escopo, foram realizadas pesquisas de campo; entrevistas com cortadores de cana e com outros informantes-chave; teste ergométrico; monitoramento da frequência cardíaca durante o trabalho no canavial e aplicação de Questionário Nórdico de Sintomas Osteomusculares - procedimentos realizados com a colaboração de médicos e educadores físicos. Os dados levantados apontam para a existência de relação direta entre o trabalho nos canaviais alagoanos e o esgotamento prematuro das energias físicas e espirituais dos trabalhadores.

Palavras-chaves: trabalho rural; agroindústria canavieira; exploração; saúde; Alagoas.

\footnotetext{
1 Este artigo é uma versão ampliada e revisada do texto apresentado no $7^{\circ}$ Encontro da Rede de Estudos Rurais. Ele é fruto da pesquisa de doutorado, intitulada "Os saltos do 'canguru' nos canaviais alagoanos. Um estudo sobre trabalho e saúde", que contou com financiamento da Anpocs e Fapesp sob a orientação da professora Maria Aparecida de Moraes Silva. O projeto de pesquisa foi aprovado pelo Comitê de Ética em Pesquisa do Cesmac (parecer número 786.421). A tese foi defendida em março de 2016 no Programa de Pós-graduação em Sociologia da Universidade Federal de São Carlos (UFSCar).

* Doutor em Sociologia pela Universidade Federal de São Carlos (UFSCar) e professor da Sociedade de Ensino Universitário do Nordeste (Seune), Maceió, AL, Brasil; e-mail: luciovercoza@yahoo.com.br ** Doutora em Sociologie du Dévéloppement (IEDES) - Université Paris I (Panthéon-Sorbonne); Professora livre-docente visitante do Programa de Pós-graduação em Sociologia da Universidade Federal de São Carlos (UFSCar), São Carlos, SP, Brasil; e-mail: maria_moraes@terra.com.br
} 
ABSTRACT: This text aims to study the working conditions and health in the face the current situation of sugarcane agribusiness in Alagoas: characterized by productive restructuring and the intensification of work in manual cutting of sugarcane. The increased effort required in this labor activity produces besides the physical, moral and psychological distress. The main objective of this research was to contribute to the reflections on the causal connection between illness and the cane cutting job. To achieve this scope, field research and interviews were carried out with cane cutters, among other key informants; furthermore it was performed exercise testing, monitoring heart rate during labor, application Nordic Musculoskeletal Questionnaire - procedures performed with the collaboration of doctors and fitness trainers -. The data collected indicate existence of direct relationship between work in the cane fields and the early exhaustion of physical and spiritual energies of workers.

Keywords: rural labor; sugar cane agro industry; exploration; health; Alagoas.

\section{INTRODUÇÃO}

Em pesquisas anteriores, deparamo-nos com diversos trabalhadores canavieiros que conviviam com dores, cãibras e cicatrizes no corpo e na alma. Esses relatos eram recorrentes, tanto em São Paulo quanto em Alagoas (Silva, Verçoza e Bueno, 2013; Silva, Bueno e Verçoza, 2013). Após várias safras de labor, grande parte desses trabalhadores não consegue mais se empregar no corte da cana - a maioria das usinas alagoanas exige que seja cortada uma média mínima diária de sete toneladas. Para além da condição de "inempregável", existem enormes dificuldades para comprovar o nexo causal entre o trabalho e o adoecimento. Devido ao próprio limite de alcance das pesquisas supracitadas, não pudemos analisar essas questões de modo aprofundado naquele período.

Por isso, no presente estudo, a problemática investigada é a análise dos elos que ligam o trabalho ao adoecimento. Cabe sub- 
linhar que o mais recente processo de reestruturação produtiva da agroindústria canavieira alagoana, iniciado a partir de 1990, acarretou drástica intensificação do trabalho no corte manual da canade-açúcar (Mello, 2002; Carvalho, 2009; Albuquerque, 2009). O aumento do esforço exigido nessa atividade se expressa tanto pela alarmante elevação das metas mínimas de produção, quanto pela forma de sequelas no corpo e na mente dos trabalhadores. A presente investigação propõe a análise da saúde física dos trabalhadores canavieiros, articulada ao sofrimento moral e psíquico, e um diálogo com as pesquisas da mesma temática em São Paulo. Desse modo, o intuito é de contribuir para o desvelamento do nexo causal e para a apreensão das particularidades desse labor em Alagoas.

Apesar de sua pequena extensão territorial, o estado de Alagoas é o sexto maior produtor nacional de cana-de-açúcar, e primeiro da região Nordeste (CONAB, 2016). Todavia, essa expressiva imagem numérica, por si só, não revela como são produzidos os canaviais, não ajuda a compreender o porquê de tantos canavieiros adoecerem e se acidentarem no trabalho ${ }^{2}$. Em busca de elucidar tal questão, realizamos pesquisa de campo, entrevistas com cortadores de cana e outros informantes-chave (norteadas pela metodologia da história oral), teste ergométrico, monitoramento da frequência cardíaca durante a jornada de trabalho e aplicação de Questionário Nórdico de Sintomas Osteomusculares ${ }^{3}$; desse modo, analisamos os seguintes aspectos: 1) a carga cardiovascular (dispêndio de energia) durante o trabalho nos canaviais alagoanos; 2) o gasto calórico médio da jornada laboral; 3) quais regiões do corpo são mais afetadas pelo labor (em termos de dor); 4) o impacto do trabalho no fundo do ser.

A partir desses resultados, dialogamos, comparativamente, com pesquisas realizadas nos canaviais paulistas. A amostra da investigação consistiu em 22 trabalhadores safristas (voluntários), habitan-

2 Em 2012, 59\% dos acidentes de trabalho registrados em Alagoas foram na agroindústria canavieira (3.334 acidentes), e desses, $65 \%$ foram com trabalhadores do cultivo ou colheita de cana -2.190 acidentes. É válido mencionar que subnotificação de acidentes de trabalho ocorre com frequência nesse setor agroindustrial, portanto, o número de acidentes pode ser ainda maior do que os que foram registrados. Nesse mesmo ano, foram registradas 5 mortes por acidente de trabalho em terras de usinas alagoanas (MTE, 2013).

3 Os procedimentos médicos foram coordenados pelo cardiologista Roberto Lúcio de Gusmão Verçoza (Hospital do Coração de Alagoas), as avaliações físicas ocorreram sob a coordenação do educador físico Michell Salgado Porto (Ufal). 
tes do município de Teotônio Vilela/AL, escolhidos aleatoriamente ${ }^{4}$. Elegemos essa cidade como universo empírico em razão, fundamentalmente, de este município estar localizado na principal região de produção canavieira do estado, abrigando, ainda, uma usina muito próxima da área de habitação urbana, e por ser polo concentrador de trabalhadores para diversas usinas de municípios adjacentes.

\section{O SOFRIMENTO DO TRABALHO E A NEGAÇÃO DO NEXO CAUSAL}

Conforme demonstra Laat (2010), o trabalhador no canavial paulista realiza, aproximadamente, 3.080 flexões de coluna (cerca de 1,88 flexões a cada 10 segundos) e pelo menos 3.498 golpes de facão para cortar $12.960 \mathrm{~kg}$ em um dia. Ademais, os equipamentos de proteção individual (EPIs) são, geralmente, desconfortáveis e inadequados, o que dificulta a execução dos movimentos ${ }^{5}$.

Diante do desgaste físico, intrínseco ao corte manual da cana, Alves (2007) chega a comparar o preparo físico exigido nesta atividade ao dos atletas de maratona. A comparação que Alves faz com o maratonista ilustra bem o alto nível de desgaste físico requerido no corte da cana. Todavia, existem algumas diferenças fundamentais entre o cortador de cana e um atleta que participa de competições de alto rendimento. No caso dos atletas competidores, como demonstrou Laat (2010), existe uma minuciosa preparação e um planejamento que antecedem as competições. A alimentação deve ser adequada ao tipo de atividade que o atleta exerce. Os treinamentos não podem exigir, diariamente, o limite máximo do corpo, pois isso levaria a um baixo rendimento durante as provas. A alimentação também deve ser adequada ao tipo de atividade que o atleta exerce. No caso do corte da cana, não existem treinos, todo dia de trabalho é dia de prova, ou melhor, de pro-

4 A amostra, inicialmente, foi estimada em aproximadamente 30 trabalhadores, residentes no munícipio de Teotônio Vilela, e que laboram no corte da cana. Todavia, em decorrência de demissão e mudança de função dos trabalhadores ao longo da safra, a amostra final foi reduzida. Adotamos uma amostragem não-probabilística por conveniência. O tamanho da amostra foi definido com base em trabalhos anteriores que realizaram investigações em um contexto semelhante ao nosso (Laat, 2010; Barbosa, 2010).

5 Os estudos da Fundacentro (Gonzaga, 2002; Lima \& Gonzaga, 2011) demonstram quão inadequados são alguns EPIs. 
vação. O estresse físico (ou Síndrome de Overtraining) $^{6}$ que é evitado no atleta, por meio de um treinamento balanceado, no caso do corte da cana não pode ser impedido. Para garantir o salário, que é determinado por produção, é preciso ultrapassar o limite do corpo todo dia e, na maioria das vezes, em condições de insegurança alimentar ${ }^{7}$. Nos canaviais, é uma maratona por dia de trabalho durante, pelo menos, seis meses ao ano. Como o corpo pode passar por isso sem marcas?

No universo canavieiro alagoano é comum ouvir os trabalhadores utilizando o termo "canguru” (Plancherel, Queiroz e Santos, 2010; Yabe, 2013). O fato de o "canguru" ser uma palavra consolidada no vocabulário desses trabalhadores de Alagoas indica que o mesmo ocorre com frequência. Ela é uma palavra ressignificada: o "canguru" dos trabalhadores canavieiros não significa o animal australiano, porém, uma sequela do excesso de trabalho. Nas usinas paulistas, ele também é comum, entretanto, em São Paulo é mais conhecido por outro nome: "birôla". O "canguru” ou "birôla" é descrito pelos canavieiros como "um tipo de fraqueza que dá na gente, e chega cãibra por todos os cantos". Abaixo segue o fragmento de uma entrevista que ilustra bem esse quadro:

Entrevistado: Umas duas horas da tarde deu uma cãibra na coxa. Cãibra foi essa que eu caí no chão e comecei a gritar... Quando o vizinho de eito chegou lá eu já estava todo entrevado. Apesar disso ter acontecido, ainda foram esperar os trabalhadores acabar, para poder a gente vir embora. Até por baixo da língua dava cãibra. Se eu fizesse qualquer movimento brusco que usasse algum nervo, dava cãibra. Costela, barriga... por todo canto, onde tem músculo, a cãibra pegou. Vomitei verde, bem verde mesmo: aquela água verde... Estado, digamos assim: de morte mesmo! Que chega a um ponto que a pessoa não sente nada. É tanta dor no corpo, que mais nada que aconteça a pessoa sente. [...] Calado, justamente para não fazer força. Para não fazer nenhum movimento brusco. [...] O desengano veio e a primeira coisa que eu pensei foi: se eu morrer eu não vou ver minha mãe de

6 De acordo com Barbosa (2010, p. 22) a Síndrome de Overtraining "é compreendida por sinais e sintomas caracterizados por diminuição da performance, fadiga, alterações do sono, diminuição de peso, aumento dos níveis séricos de lactato, alterações hormonais, imunológicas, hematológicas e psicológicas". 7 A pesquisa realizada pela nutricionista Carla Santos (2011) demonstrou que a maior parte dos trabalhadores canavieiros alagoanos investigados encontrava-se em condições de insegurança alimentar. 
novo. Foi quando no meio de tanta dor veio o choro. Foi bem difícil mesmo. $\mathrm{O}$ desengano chega num momento, e é difícil de sair. $\mathrm{O}$ choro foi só lágrima. Porque nem força dava, quando bateu aquele tranco na garganta... [..] Uma teoria que o povo usa aqui... me enrolaram de borracha, que dizem que borracha acalma a cãibra. E de certa forma acalmou um pouco. Era borracha de câmara de ar. Amarraram nos meus braços, nas pernas, barriga, pescoço. É um negócio que não é de se acreditar muito, mas de certa forma acalmou um pouco.

Esses casos de "canguru" ou "birôla" multiplicam-se nos eitos da cana. Eles são recorrentes. Um trabalhador nos relatou que quem vivencia esse processo generalizado de cãibras costuma encolher os braços junto ao corpo, de tal forma, que se assemelha a posição das patas do canguru australiano. Para o entrevistado o nome "canguru" decorre dessa trágica e surreal semelhança. $\mathrm{O}$ "pulo do canguru" vai se transfigurando em perda de si. O corte de cana torna-se corte de si. O trabalhador estranha os seus movimentos, não se reconhece naquela convulsão autônoma. Está diante de si como se estivesse diante de um "canguru". Está diante da cana como se estivesse diante de um ente personificado que o transfigura. Desse modo, o "animal se torna humano e o humano animal" (Marx, 2004, p. 181).

Esse fenômeno é desencadeado pelo altíssimo nível de esforço exigido nesse trabalho, que é realizado sob calor inimaginável, em longas jornadas laborais, com movimentos repetitivos em posições flexionadas, para alcançar uma média mínima diária de sete toneladas de cana cortada - aliás, mais do que isso, pois, no cálculo que converte o quantum que efetivamente foi cortado em toneladas ocorrem fraudes constantes. Não é por acaso que pululam casos de "canguru", conhecidos na medicina como distúrbio hidroeletrolítico. Ele está relacionado à desidratação, perda de eletrólitos e de sais minerais; e, em alguns casos, se não for tratado a tempo, pode levar à morte ${ }^{8}$. Nos meses de safra não é raro encontrar cortadores de cana recebendo soro na veia em postos de saúde ou hospitais dos municípios canavieiros.

8 Segundo o médico de uma usina alagoana, o "canguru" pode resultar em "morte, porque é um distúrbio hidroeletrolítico, e isso mexe com as células, que são as unidades fundamentais, e se não for atendido, hidratado e não tiver repostos esses eletrólitos, pode acontecer" o óbito. 
No entanto, cabe ainda frisar, na esteira de Weil (1996), que esse processo deve ser compreendido para além da fadiga do corpo dos trabalhadores, pois existe ainda a fadiga na alma. Afinal, como é possível que casos como a perda de controle sobre os movimentos do próprio corpo durante o trabalho ("canguru" ou "birôla") - experiência extrema de estranhamento do ser - não atinja também a subjetividade dos trabalhadores? Como é possível aguentar tais agruras? Como afirma Silva (2009, p. 23), a "barbárie produzida no i-mundo do trabalho atinge o fundo de ser, da condição humana".

A pesquisa de Alessi e Navarro (1997), realizada na macrorregião de Ribeirão Preto/SP e desenvolvida com observações diretas, entrevistas semiestruturadas com cortadores de cana e outros informantes-chave, verificação dos registros médicos e dos dados encontrados nas Comunicações de Acidente de Trabalho (CAT), concluiu que:

A exposição diária dos cortadores de cana a cargas físicas, químicas e biológicas, que se traduzem em uma série de doenças, traumas, ou acidentes a elas relacionadas: dermatites, conjuntivites, desidratação, câimbras, dispneias, infecções respiratórias, alterações da pressão arterial, ferimentos e outros acidentes; destacando-se também cargas biopsíquicas configurando padrões de desgaste manifestos através de dores na coluna vertebral, dores torácicas, lombares, de cabeça, e tensão nervosa e outros tipos de manifestações psicossomáticas. (Alessi \& Navarro, 1997, p.12)

Além dessa extensa lista de sequelas, os movimentos repetitivos e monótonos, realizados com altíssima intensidade, fazem com que muitos trabalhadores sejam "acometidos por Lesões por Esforços Repetitivos e Doenças Osteomusculares (LER/DORT)" (Santos, 2011, p.31). Nogueira (2013), ao investigar essa questão, conclui que a maior parte de trabalhadores acometidos por essas doenças encontra uma série de dificuldades para conseguir retornar a suas atividades laborais.

Apesar da evidente relação entre essas doenças e o trabalho no corte da cana - não precisamos de muito para enxergar os fios que os unem, uma simples descrição de como se dá essa atividade labo- 
rativa já revela seu caráter insalubre -, o não reconhecimento desse nexo é prática corriqueira pelos médicos peritos do INSS. Como demonstraram as pesquisas do Diesat $^{9}$ (1989), a negação desse nexo é antiga e não se restringe ao trabalho no corte da cana.

Em pesquisa envolvendo entrevistas com médicos da Perícia Médica do INSS/RJ, com trabalhadores lesionados por LER, que encaminhavam processos de requisição de nexo causal a essa mesma Perícia e análise de dados dos respectivos processos, Vertheim e Manayo Gomes (2001, pp.468 e 469), concluíram que, na perspectiva da Perícia Médica:

1) Os distúrbios osteomusculares, comuns nos trabalhadores que executam atividades de esforço muscular e repetitividade, são analisados sem o reconhecimento do trabalho na deflagração da patologia, por serem considerados em grandes grupos de doenças crônicas ou degenerativas que podem acometer as pessoas em geral.

2) A existência de uma personalidade que predispõe o trabalhador, em situações de conflito e tensão, a processos de adoecimento. As dificuldades no trabalho, assim como as pressões de instabilidade social, estariam entre os elementos ansiogênicos.

3) As LER não seriam propriamente "doenças", mas um conjunto de sintomas de doenças dos nervos ou de estresses que acometeriam determinados "sujeitos predispostos" a transtornos mentais ou somatizações.

Assim, a ideia de um "sujeito-doente" pressupõe um certo tipo de personalidade de características mórbidas que expressa sintomas de doença em ambientes ansiogênicos e estressantes. Ao colocar em suspenso as atividades realizadas no trabalho vai destruindo, de forma estratégica, o campo de possibilidade do trabalho como elemento constituinte desse processo de adoecimento.

$[\ldots]$

Tal relação mostra a radical separação entre trabalho e corpo-que-adoece. Esta separação acaba encontrando uma ancoragem na ideia de predisposição, posto que, nesse distanciamento do INSS quanto ao desenvolvimento das relações de trabalho, sejam elas prejudi-

9 Departamento Intersindical de Estudos e Pesquisas de Saúde e dos Ambientes de Trabalho. 
ciais ou não, o processo de adoecimento passa a ser encarado como efeito de alterações "psicogênicas".

Essa lógica de separação do "corpo-que-adoece" do trabalho que este "corpo" executa (ou executou), pressupõe conceber o corpo como algo meramente biológico. Segundo Laurell e Noriega, um dos postulados fundamentais do pensamento médico, "é o caráter a-histórico da biologia humana" (1989, p.100). Nessa concepção, o corpo seria tanto a-histórico como não social. O encontro desse tipo de racionalidade instrumental (Adorno; Horkheimer, 1985) com as políticas neoliberais de redução dos benefícios previdenciários, gera uma "confluência perversa"10, que tem como consequências tanto a negação sistemática do reconhecimento de nexo causal entre o adoecimento e o trabalho, quanto a impossibilidade de o trabalhador acessar direitos fundamentais no momento em que mais precisa: justamente quando não dispõe de sua força de trabalho, que foi prematuramente consumida.

No que tange ao tema das políticas de previdência, Sara Granemann (2013, p. 239 e 240) faz a seguinte análise:

$1^{\circ}$ ) no cotidiano da vida laboral da classe trabalhadora, saúde e aposentadoria somente constituem-se preocupações por ausência, em geral, de uma ou de ambas; dito de outro modo, é quando a força de trabalho apresenta alguma dificuldade - quase sempre determinada pelos processos de trabalho mesmo a que está submetida - para cumprir, do ponto de vista do capital, a sua jornada de trabalho de modo ótimo que suas saúde e idade são compreendidas como problemas pelo próprio trabalhador, por seu empregador e pelo Estado; $2^{\circ}$ ) a proteção social, embora seja crucial à vida da força de trabalho, inexiste para significativos contingentes da classe pelo planeta; tampouco, as frações e categorias profissionais que a conquistaram como direito - neste aspecto, não há países capitalistas como ex-

10 Tomamos esse termo emprestado de Dagnino (2004), que o utiliza em outro contexto: o da crise discursiva gerada pela semelhança de termos do projeto neoliberal e do projeto do campo autodenominado "democrático popular". No nosso caso trata-se da confluência das políticas previdenciárias neoliberais com o paradigma médico dominante. 
ceções dignas de nota - podem desfrutar da tranquilidade de tê-la em definitivo. Nada mais dolorosamente didático nos dias atuais, especialmente aos que devotam esperanças no Estado de direito, do que perceber - e não somente em períodos de crise do capital: sob a ordem do capital, todos os direitos dos trabalhadores são passíveis de regressão e de supressão; $3^{\circ}$ ) discutir saúde do trabalhador e previdência social implica ter claro que a força de trabalho utilizada ao limite pelo capital - e por seu Estado - pode tornar-se consumidora destes dois direitos quando metamorfoseados em mercadorias. Claro está, tal argumento somente tem validade para as frações mais bem-remuneradas da classe trabalhadora, aquelas a que é possível converter o desgaste e a exaustão das forças "físicas e espirituais" (Marx, 1983) em oportunidades lucrativas para os capitais. Referimo-nos às possibilidades de lucro decorrentes da mercantilização da saúde (a pública e a "suplementar"), dos seguros por acidentes do trabalho e da aposentadoria (a "complementar", aberta e fechada).

A imensa maioria dos trabalhadores dos canaviais alagoanos somente acessou o mundo dos direitos trabalhista e previdenciário em meados dos anos 1990, após a constituinte de 1988. Todavia, esse acesso deu-se justamente no momento de ajustes neoliberais, marcado pela regressão dos direitos sociais recém-conquistados. Outro caráter aparentemente contraditório, diz respeito ao fato de a entrada no mundo do direito ter sido acompanhada pelas crescentes metas draconianas de produção, que aceleram a exaustão das "forças físicas e espirituais" (Marx, 1985) do cortador de cana. O trabalhador exaurido, no momento de maior insegurança da sua vida e de seus familiares, defronta-se com o saque dos direitos, que foram "metamorfoseados em mercadorias", mercadorias essas (previdência privada, seguro por acidente, plano de saúde...), que o cortador de cana não pode comprar. Resta o drama das filas do INSS, a destinação de parte dos parcos recursos financeiros para pagar exames que não são realizados pelo $\mathrm{SUS}^{11}$ (ou que são realizados depois de longos meses de espera), na

11 Muitas vezes, os parentes contribuem no levantamento de recursos para cobrir essas despesas. A solidariedade familiar é algo indispensável para a reprodução social desses trabalhadores extremamente pauperizados. 
esperança de comprovação do nexo causal e da liberação do benefício ou da aposentadoria, que, muitas vezes, são negados.

No que diz respeito à concepção médica dominante (que se recusa a reconhecer o caráter social e histórico do processo saúdedoença), Laurell (1982, p. 12), faz um relevante contraponto:

[...]Por um lado, o processo saúde-doença do grupo adquire historicidade porque está socialmente determinado. Isto é, para explicá-lo, não bastam os fatores biológicos, é necessário esclarecer como está articulado no processo social. Mas o caráter social do processo saúde-doença não se esgota em sua determinação social, já que o próprio processo biológico humano é social. É social na medida em que não é possível focalizar a normalidade biológica do homem à margem do momento histórico. Isso se expressa, por exemplo, no fato de que não é possível determinar qual é a duração normal do ciclo vital, por ser ele diverso em diferentes épocas. Isto leva a pensar que é possível estabelecer padrões distintos de desgaste-reprodução, dependendo das características da relação entre o homem e a natureza.

Se desta maneira a "normalidade" biológica define-se em função do social, também a "anormalidade" o faz, fato que demonstramos na primeira parte deste trabalho. O caráter simultaneamente social e biológico do processo saúde-doença não é contraditório, porém unicamente assinala que pode ser analisado com metodologia social e biológica, na realidade, como um processo único.

As formulações de Laurell, sugerem que o nexo causal da doença com o trabalho não pode ser encontrado, se analisarmos somente os fatores biológicos; é necessário estabelecer as relações desses fatores com os processos sociais. Para a autora, essa característica simultaneamente social e biológica dos processos de saúdedoença assinala que eles podem ser analisados "com metodologia social e biológica, na realidade, como um processo único".

Antes de adentrarmos à análise que articula o processo social com alguns indicadores biológicos, é importante frisar, que, mesmo 
nos casos de acesso a benefícios previdenciários e à aposentadoria, o sofrimento perdura. Entrevistamos um trabalhador que estava há dois anos afastado do serviço. Na infância, ele foi morador de usina e, com 14 anos de idade, assumiu pela primeira vez o eito sozinho. Já adulto, chegava a cortar até 15 toneladas de cana em um dia. Desmaiou duas vezes em decorrência do "canguru" - "É a mesma coisa de você estar morrendo. Você revira os olhos e não consegue falar" -, disse. Nos últimos anos da sua vida laboral, sentia dores insuportáveis na coluna e no ombro. Recorria à automedicação para prosseguir no trabalho. Atualmente, ele se encontra com 48 anos de idade e tem dias que não consegue levantar, sequer, uma colher. A cada cinco meses, vai ao INSS de São Miguel dos Campos levando novos exames (pagos por ele na rede particular) para renovar o benefício junto à Perícia Médica. No fim da entrevista, perguntei-lhe:

Pesquisador: Qual o sonho que o senhor gostaria de realizar?

Entrevistado: Rapaz, eu não tenho mais nenhum. Não tenho mais nada para realizar, é só esperar a hora de morrer mesmo.

\section{EM BUSCA DO NEXO CAUSAL}

A tese de Erivelton Laat (2010), que teve o objetivo de identificar os determinantes do trabalho que podem afetar a saúde dos canavieiros, calculou a carga cardiovascular (medida utilizada para mensurar a carga de trabalho físico - ou dispêndio de energia) de trabalhadores nordestinos que migram para o corte da cana, em Piracicaba/SP. Após análise da frequência cardíaca no grupo de 37 trabalhadores, conclui-se que "pela média da carga cardiovascular de cada trabalhador, consagrado como parâmetro na literatura, já se pode confirmar a existência do risco e desgaste na colheita manual de cana-de-açúcar" (Idem, p. 167). Além disso, Laat, com o uso do Índice de Bulbo Úmido Termômetro de Globo (IBUTG), encontrou extrapolação do limite de sobrecarga térmica, algo que representa um grave risco ao trabalhador. Por meio do uso do software Captiv versão L3000, o autor constatou que, durante a jornada laboral, os 
trabalhadores realizam cerca de 3.080 flexões de coluna e pelo menos 3.498 golpes de facão. No corte de cana tipo rolo $\left(\right.$ moroba $\left.^{12}\right)$, a postura flexionada ocupa $62 \%$ do tempo total de trabalho.

Seguindo a trilha aberta por Laat, decidimos mensurar a carga cardiovascular de trabalhadores canavieiros alagoanos. Essa questão, que nos parece altamente relevante, pode contribuir na elucidação da hipótese de que o elevado dispêndio de energia requerido nesse labor acarreta desgaste prematuro da força de trabalho. Ademais, esse dado pode ser útil na apreensão das particularidades desse labor em Alagoas.

Antes de iniciarmos a exposição sobre os índices de carga cardiovascular, convém esclarecer algo importante: uma determinada tarefa, realizada por pessoas com aptidões cardiorrespiratórias (aptidão física) muito distintas, resultam em cargas cardiovasculares (dispêndio de energia) também distintos. Ou seja, um sujeito com uma aptidão cardiorrespiratória muito fraca pode ultrapassar o limite seguro de carga cardiovascular cortando meia tonelada de cana, enquanto outro, com uma aptidão cardiorrespiratória excelente, pode cortar esse mesmo quantum sem ultrapassar o limite aceitável de carga cardiovascular. Le-

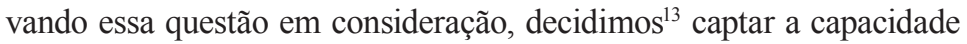
cardiorrespiratória para melhor avaliar a carga cardiovascular.

A capacidade cardiorrespiratória foi avaliada por meio de teste ergométrico. Esse exame submete o paciente a esforço físico gradualmente crescente em esteira rolante com inclinação. Além de avaliar a capacidade funcional e a condição aeróbica, ele é útil para uma ampla avaliação do funcionamento cardiovascular, servindo para diagnosticar doença arterial coronária (isquemia miocárdica), detectar arritmias, anormalidade de pressão arterial e sinais de falência ventricular esquerda (Meneghelo et al, 2010).

Os exames foram realizados nas primeiras semanas da safra 2014/2015, no Hospital do Coração de Maceió. Eles ocorreram nos três primeiros domingos do mês de novembro (dia de folga dos cortadores de cana): ao todo, 33 trabalhadores participaram dessa etapa da pesquisa. Todos eram safristas e moradores da área urbana de 12 Termo nativo, utilizado pelos trabalhadores canavieiros alagoanos, para designar canas deitadas (que dificultam o trabalho do cortador e proporcionam o rebaixamento da produção de toneladas cortadas). 13 Em conjunto com o médico cardiologista Roberto Lúcio de Gusmão Verçoza, que sugeriu esse encaminhamento após discussões sobre o projeto de pesquisa e acerca da tese de Laat (2010). 
Teotônio Vilela. No decurso da safra, alguns deles foram demitidos, outros realocados para outra função e também houve caso de afastamento por problema de saúde. A amostra final foi de 22 trabalhadores. Abaixo segue imagem do momento do exame:

Figura 1 - Teste ergométrico com esteira inclinada

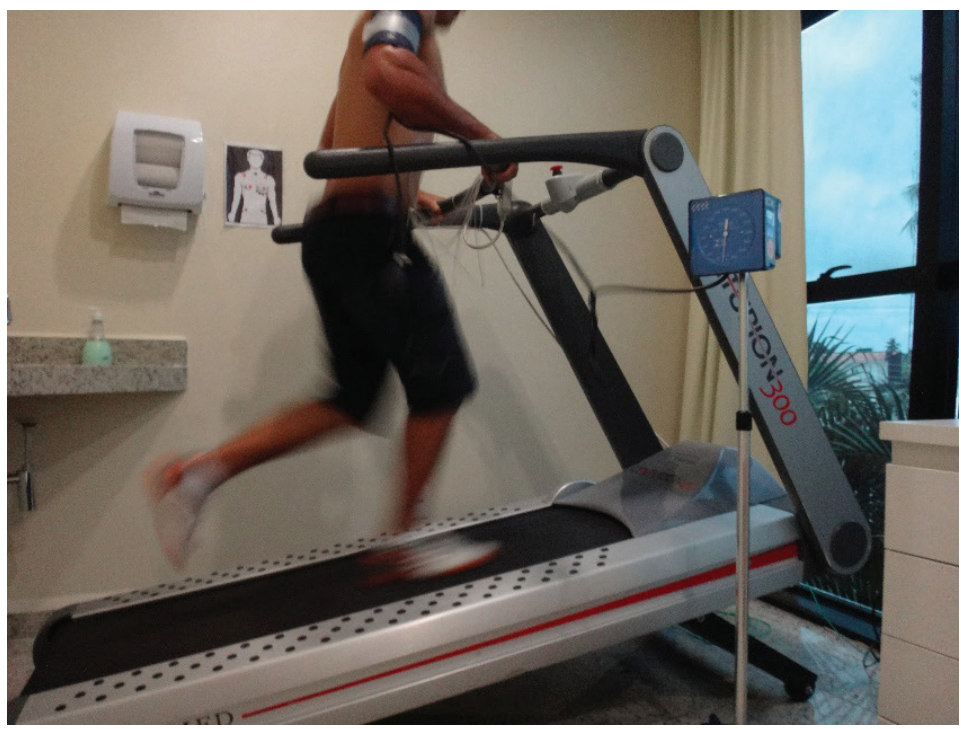

Fonte: Lúcio Verçoza, 2014

Os exames não detectaram casos de cardiopatia e demonstraram que a maior parte dos trabalhadores examinados tem capacidade cardiorrespiratória (medida em VO2 Max.) excelente. Abaixo segue a tabela com a aptidão cardiorrespiratória da amostra final: 
Tabela 1 - Aptidão Cardiorrespiratória

\begin{tabular}{|c|c|c|c|}
\hline Cortadores & Idade & VO2 Max. & $\begin{array}{l}\text { Índice } \\
\text { AHA }\end{array}$ \\
\hline 1 & 44 & 62,91 & Excelente \\
\hline 2 & 40 & 69,45 & Excelente \\
\hline 3 & 42 & 62,09 & Excelente \\
\hline 4 & 34 & 54,35 & Excelente \\
\hline 5 & 31 & 66,85 & Excelente \\
\hline 6 & 40 & 67,03 & Excelente \\
\hline 7 & 20 & 70,74 & Excelente \\
\hline 8 & 48 & 45,65 & Excelente \\
\hline 9 & 44 & 52,63 & Excelente \\
\hline 10 & 31 & 67,62 & Excelente \\
\hline 11 & 37 & 60,00 & Excelente \\
\hline 12 & 33 & 49,84 & Excelente \\
\hline 13 & 36 & 52,31 & Excelente \\
\hline 14 & 23 & 49,18 & Boa \\
\hline 15 & 27 & 45,72 & Boa \\
\hline 16 & 34 & 55,86 & Excelente \\
\hline 17 & 44 & 53,28 & Excelente \\
\hline 18 & 26 & 44,71 & Boa \\
\hline 19 & 46 & 42,65 & Boa \\
\hline 20 & 50 & 53,07 & Excelente \\
\hline 21 & 24 & 51,83 & Boa \\
\hline 22 & 21 & 68,66 & Excelente \\
\hline Média & 35,22 & 56,65 & Excelente \\
\hline
\end{tabular}

Fonte: Dádos primários: V̇O2: Volume de Oxigênio Máximo, Índice da American Heart Association

A média de aptidão cardiorrespiratória dos cortadores de cana avaliados é excelente. Alguns deles detêm uma capacidade física impressionante, com índices típicos de corredores de longa distância (Aguiar et al, 2015) - os resultados mais extraordinários foram destacados de vermelho. Os dados levantados corroboram a análise de Alves (2006, p. 94): 
é necessário ter maior resistência física para a realização de uma atividade repetitiva e exaustiva, realizada a céu aberto, sob o sol, na presença de fuligem, poeira e fumaça, por um período que varia entre 8 e 12 horas.

Posteriormente veremos como esses dados serão relevantes para a análise da carga cardiovascular. Por enquanto, cabe esclarecer alguns aspectos dessa forma de medir o esforço despendido em determinada atividade.

De acordo com Edholm (1968), a frequência cardíaca é um importante indicador para avaliar o dispêndio de energia do trabalho, pois ela é um indicador confiável e de fácil registro. Para obter a carga cardiovascular (CCV), utilizamos a equação proposta por Apud (1989):

$$
\mathrm{CCV}=\frac{(\mathrm{FCmt}-\mathrm{FCrp})}{(\mathrm{FCmax}-\mathrm{FCrp})} * 100
$$

Em que: CCV - carga cardiovascular em \%

FCmt - frequência cardíaca média durante a jornada de trabalho

FCrp - frequência cardíaca de repouso

FCmax - frequência cardíaca máxima teórica estimada pela fórmula (220 - idade)

Segundo Rodgers (1986), 33\% é o limite aceitável do percentual da máxima carga cardiovascular utilizada para uma jornada de trabalho. No que concerne, especificamente, ao corte manual da cana, Lambers et al (1994), indicam o valor de 30\% como limite máximo, pois essa atividade é realizada em ambiente com altas temperaturas e com roupas de difícil dissipação de calor. Grandjean (1988) também propõe um método para estabelecer o limite da carga laboral por meio dos batimentos cardíacos; o autor indica que este deve ser de 35 batimentos do coração por minuto, acima da frequência cardíaca em repouso, tendo em vista uma atividade contínua. 
Para obter a carga cardiovascular do trabalho, foi realizado o acompanhamento da frequência cardíaca ao longo da jornada laboral. Os dados foram levantados mediante o uso do monitor de frequência cardíaca, modelo Polar RC3 GPS, que foi ativado minutos antes dos trabalhadores entrarem no ônibus que os leva ao eito; no fim da jornada laboral, após retornarem para cidade, o monitor era desligado. A cada dia monitorávamos os batimentos cardíacos de um ou, no máximo, dois trabalhadores ${ }^{14}$. Os dados foram coletados entre os dias 17 de novembro e 22 de dezembro de 2014.

Abaixo, segue a tabela com frequência cardíaca média em repouso, máxima teórica, carga cardiovascular, diferença de batimentos por minuto e toneladas de cana cortada:

Tabela 2 - Batimentos cardíacos, carga cardiovascular e produção

\begin{tabular}{|c|c|c|c|c|c|c|c|}
\hline Cortadores & Idade & $\begin{array}{c}\text { Fc } \\
\text { maxr } \\
\text { (bpm) }\end{array}$ & $\begin{array}{l}\text { Fcmt } \\
(\text { bpm) }\end{array}$ & $\begin{array}{c}\text { Fec } \\
\text { Rep } \\
\text { (bpm) }\end{array}$ & $\operatorname{CCV}(\%)$ & $\begin{array}{l}\text { Fcmt - } \\
\text { FecRep }\end{array}$ & $\begin{array}{l}\text { Produção } \\
\text { (Ton) }\end{array}$ \\
\hline 1 & 44 & 133 & 93 & 50 & 34,12 & 43 & 6 \\
\hline 2 & 40 & 150 & 102 & 55 & 37,60 & 47 & 10 \\
\hline 3 & 42 & 142 & 92 & 48 & 33.84 & 44 & 13 \\
\hline 4 & 34 & 155 & 102 & 62 & 32.25 & 40 & 4 \\
\hline 5 & 31 & 175 & 112 & 56 & 42,10 & 56 & 4,5 \\
\hline 6 & 40 & 135 & 100 & 53 & 37.00 & 47 & 9,8 \\
\hline 7 & 20 & 189 & 108 & 63 & 32.84 & 45 & 6 \\
\hline 8 & 48 & 126 & 89 & 48 & 33,06 & 41 & 6,5 \\
\hline 9 & 44 & 134 & 83 & 42 & 30,59 & 43 & 4,2 \\
\hline 10 & 31 & 161 & 107 & 60 & 36.43 & 47 & 5,5 \\
\hline 11 & 37 & 140 & 88 & 45 & 31.15 & 43 & 10 \\
\hline 12 & 33 & 141 & 100 & 50 & 36.49 & 50 & 6,5 \\
\hline 13 & 36 & (187) & 112 & 46 & 46,15 & 66 & 9,8 \\
\hline 14 & 23 & 189 & 114 & 48 & 43,33 & 65 & 6,8 \\
\hline 15 & 27 & 160 & 102 & 47 & 37,67 & 55 & 6,5 \\
\hline 16 & 34 & 169 & 101 & 55 & 35,11 & 46 & 7 \\
\hline 17 & 44 & 145 & 102 & 57 & 37,81 & 45 & 8 \\
\hline 18 & 26 & 200 & 107 & 50 & 39,58 & 57 & 7 \\
\hline 19 & 46 & 173 & 98 & 53 & 37,19 & 45 & 7,5 \\
\hline 20 & 50 & 159 & 95 & 50 & 36,75 & 45 & 9 \\
\hline 21 & 24 & 186 & 109 & 56 & 39,16 & 53 & 8,7 \\
\hline 22 & 21 & 181 & 105 & 59 & 35,61 & 46 & 6,3 \\
\hline Média & 35,22 & 163,18 & 100,95 & 49,77 & 36,62 & 48,59 & 7,3 \\
\hline
\end{tabular}

Fonte: Dados primários

Fcm: frequência cardíaca média durante a jornada de trabalho

Fc Rep: frequência cardíaca de repouso

Fc max: frequência cardíaca máxima teórica estimada pela fórmula (220 - idade)

Fc maxr: frequência cardíaca máxima real, atingida durante o trabalho

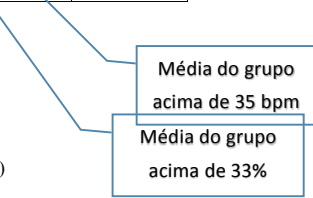

CCV: carga cardiovascular em \%

Produção: produção do dia em toneladas

Idade: em anos

Fcm - Fc Rep: diferença entre frequência cardíaca de repouso

e frequência cardíaca média

Obs: dados em vermelho ultrapassam o limite de CCV

14 Só dispúnhamos de dois frequencímetros, além disso, em algumas ocasiões, os trabalhadores partiam de pontos diferentes da cidade, e não era possível estar em dois lugares ao mesmo tempo. 
Nota-se que somente 4 trabalhadores não extrapolaram a carga cardiovascular limite de 33\%. Dentre eles, dois foram os que produziram menos toneladas. Ao todo, $81,82 \%$ ultrapassaram o limite da carga física de trabalho. Esse dado tenebroso, é semelhante aos $82,26 \%$ obtidos por Laat (2010), ao analisar uma turma de 36 trabalhadores.

Destacam-se alguns trabalhadores que ultrapassaram o limite de carga cardiovascular em níveis extremos, como a situação alarmante do trabalhador " 13 ", que atingiu $46,15 \%$ de CCV, com uma produção de 9,8 toneladas de cana cortada. A média de CCV do grupo foi de $36,62 \%$, número muito próximo dos " $36,68 \%$ de média" encontrada por Laat (2010, p. 160).

Também é preocupante o fato de todos trabalhadores terem superado a diferença entre a frequência cardíaca média e a frequência cardíaca de repouso, prescrita pela literatura como 35 batimentos por minuto. A média da amostra foi de 49,77 batimentos de diferença ${ }^{15}$.

Os resultados também demonstram incidência de elevadíssimos índices de frequência cardíaca máxima. Os trabalhadores "13" e "18" ultrapassaram o limite da frequência máxima teórica, chegando, respectivamente a picos críticos de 187 e 200 batimentos por minutos. De acordo com Domingues Filho (1993, apud Laat, 2010 p. 155): "Nenhuma atividade física deverá ultrapassar esse limite crítico, com risco imediato de complicações à saúde, pois a frequência cardíaca máxima teórica é o número máximo de batimentos que o coração pode atingir por minuto durante um determinado esforço".

Abaixo, segue o gráfico com os dados do monitoramento da frequência cardíaca do trabalhador " 18 ":

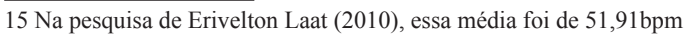


Gráfico 1 - Dados detalhados do monitoramento da frequência cardíaca do trabalhador " 18 "

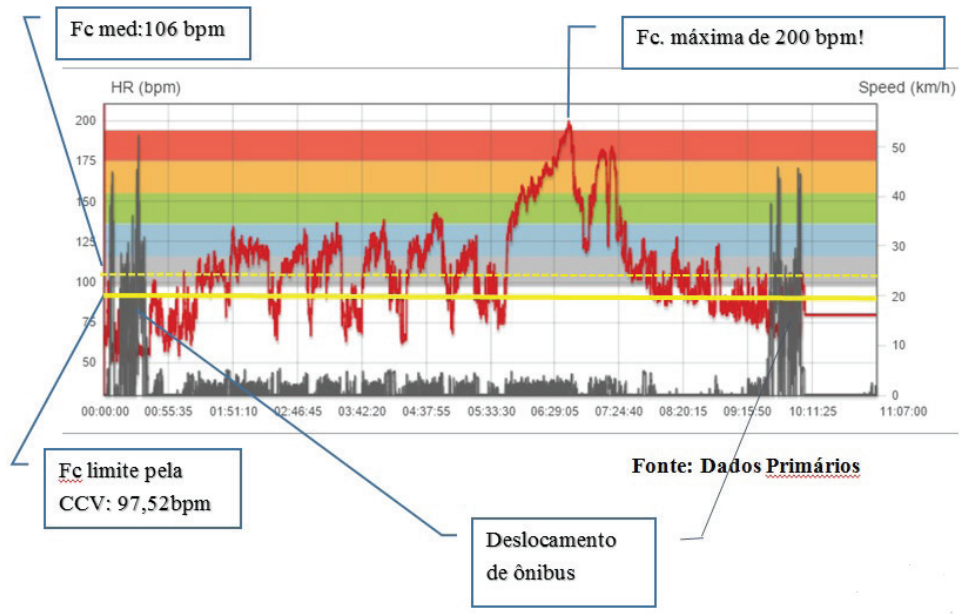

Os dados, coletados no dia 19 de novembro de 2014, demonstram que o trabalhador " 18 ", ao longo de uma jornada de mais de 10 horas, atingiu o pico de $200 \mathrm{bpm}$ (seu limite máximo teórico é de 194 bpm!). Observa-se que esse número extremo de batimentos cardíacos foi alcançado após, aproximadamente, uma hora de trabalho ininterrupto e em ritmo frenético. $\mathrm{O}$ trabalhador revelou-nos que no ápice da aceleração dos batimentos sentiu o coração "saindo pela boca”. Também é possível constatar que sua frequência cardíaca média - destacada na linha pontilhada amarelada - foi bastante superior à frequência limite de carga vascular (marcada pela linha amarela contínua). Em 53\% do tempo monitorado, o trabalhador esteve acima da frequência limite de CCV.

Nesse dia, o trabalhador " 18 " cortou 7 toneladas de cana do tipo em pé (reta). Para lograr tal desempenho, ingeriu dez litros de água, caminhou aproximadamente 6 quilômetros e teve um gasto calórico de $4.395 \mathrm{kcal}$. É válido sublinhar, que esse trabalhador esteve entre os poucos que não obtiveram uma aptidão cardiorrespiratória excelente no teste ergométrico.

A seguir, destacamos os dados relacionados ao trabalhador "13", que atingiu o mais elevado índice de carga cardiovascular do grupo, chegando aos $46,15 \%$ : 
Gráfico 2 - Dados detalhados do monitoramento da frequência cardíaca do trabalhador "13"

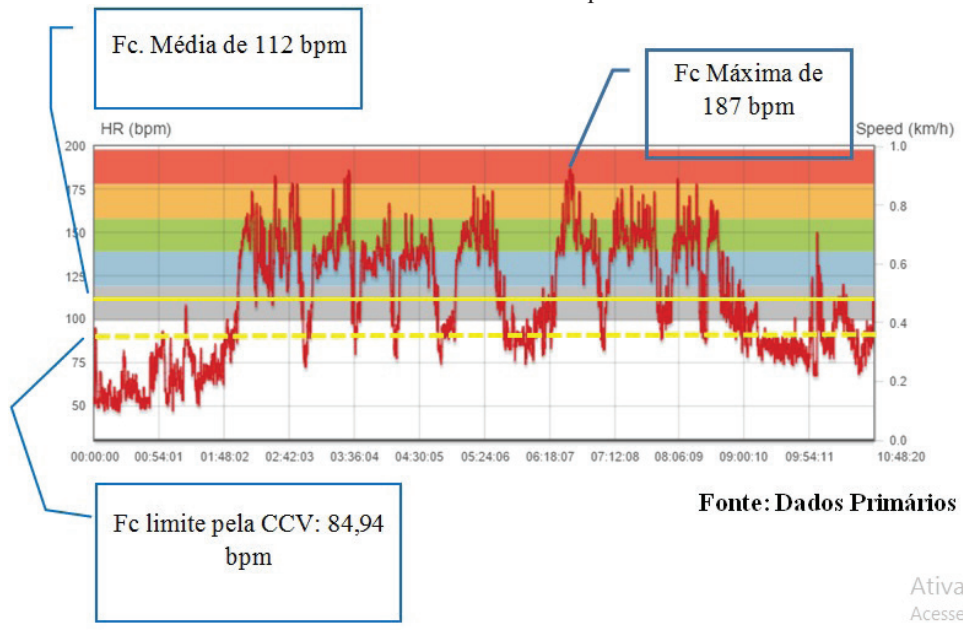

O gráfico 2 ilustra os dados coletados no dia 29 de novembro de 2014, durante uma jornada de trabalho de quase 11 horas. Nota-se que, assim como no caso do trabalhador " 18 ", a frequência cardíaca chega ao ápice após seis horas e meia de jornada, em horário de calor insuportável nos canaviais. O pico máximo do trabalhador " 13 ” foi de 187 bpm, ultrapassando o seu máximo teórico, que é de 184 bpm. Percebe-se, ainda, que sua frequência cardíaca média (destacada com a linha contínua amarela) foi flagrantemente superior à frequência limite de CCV aceitável. Também podemos atentar para a imensa diferença entre a frequência cardíaca média e a frequência cardíaca em repouso. Nesse item, o trabalhador "13" foi novamente o que apresentou dados mais alarmantes, com 66 batimentos por minuto de diferença, enquanto o limite proposto pela literatura especializada é de $35 \mathrm{bpm}$.

Esse dispêndio de energia absurdo materializou-se em 9,8 toneladas de cana cortadas. A cana era do tipo "moroba", que dificulta o trabalho e exige mais agachamentos. Nesse dia o cortador de cana "13" teve uma jornada de trabalho de quase 11 horas, ingeriu sete litros de água e alcançou um gasto calórico de $3.853 \mathrm{kgcal}$. A sua aptidão física excelente não o impediu de ultrapassar o limite de carga cardiovascular.

Conforme demonstrou Laat (2010), existe uma relação direta entre o aumento de toneladas de cana cortada e a elevação da car- 
ga cardiovascular. Entretanto, é preciso sublinhar, que essa relação é muito complexa, pois a quantidade de toneladas de cana cortada não depende exclusivamente do dispêndio de energia do trabalhador. Ainda que esse fator seja central, existem variáveis que também pesam nessa relação, como o tipo de cana (se é crua ou queimada, se é em pé ou "moroba"), o perfil do terreno (se é plano ou acidentado), a técnica do trabalhador, as condições climáticas, dentre outras.

Para ilustrar tal afirmação, recorreremos a alguns exemplos: no corte de cana crua o número de toneladas cortadas decai expressivamente, mas o dispêndio de energia do trabalhador pode ser o mesmo ou até maior. Ou então, quando o trabalhador ainda está aperfeiçoando sua técnica, ele pode cortar um quantum de cana abaixo da média, mas não necessariamente ter o dispêndio de energia inferior ao dos outros. $\mathrm{Ou}$ ainda: dois trabalhadores com técnicas semelhantes, mas com aptidões físicas muito distintas, podem cortar o mesmo número de toneladas com porcentagem de carga cardiovascular bastante discrepantes.

A tabela 3, que segue abaixo, demonstra algumas dessas complexas relações:

Tabela 3 - Carga Cardiovascular associada a outras variáveis

\begin{tabular}{|c|c|c|c|c|c|c|c|c|}
\hline Cortadores & $\begin{array}{c}\text { Gasto } \\
\text { Calórico } \\
\end{array}$ & $\begin{array}{c}\text { Tipo de } \\
\text { Cana }\end{array}$ & Tempo & $\begin{array}{c}\text { Produção } \\
\text { (Ton) }\end{array}$ & $\begin{array}{l}\text { Hidrat. } \\
\text { (Litros) }\end{array}$ & $\begin{array}{l}\text { VO2 } \\
\text { Max. }\end{array}$ & $\begin{array}{l}\text { Ind. } \\
\text { AHA }\end{array}$ & CCV(\%) \\
\hline 1 & 3.198 & moroba & $11: 58,00$ & 6 & 10 & 62,91 & Exc. & 34,12 \\
\hline 2 & 2.890 & reta & $11: 35: 46$ & 10 & 9 & 69,45 & Exc. & 37,60 \\
\hline 3 & 2.654 & reta & $10: 13: 14$ & 13 & 8 & 62,09 & Exc. & 33,84 \\
\hline 4 & 3.589 & moroba & 12:03:09 & 4 & 7,5 & 54,35 & Exc. & 32,25 \\
\hline 5 & 5.103 & crua & $11: 39: 36$ & 4,5 & 9 & 66,85 & Exc. & 42,10 \\
\hline 6 & 3.690 & reta & $11: 37: 33$ & 9,8 & 10 & 67,03 & Exc. & 37,00 \\
\hline 7 & 3.108 & reta & $11: 19: 35$ & 6 & 8 & 70,74 & Exc. & 32,84 \\
\hline 8 & 2.047 & moroba & 09:06:38 & 6,5 & 10 & 45,65 & Exc. & 33,06 \\
\hline 9 & 2.308 & moroba & $11: 05,00$ & 4,2 & 10 & 52,63 & Exc. & 30,59 \\
\hline 10 & 3.778 & moroba & 09:14:51 & 5,5 & 11 & 67,62 & Exc. & 36,43 \\
\hline 11 & 3.071 & reta & $11: 04: 37$ & 8 & 9 & 60,00 & Exc. & 31,15 \\
\hline 12 & 3.185 & moroba & $11: 05: 46$ & 6,5 & 10 & 49,84 & Exc. & 36,49 \\
\hline 13 & 3.853 & moroba & $10: 48: 20$ & 9,8 & 8 & 52,31 & Exc. & 46,15 \\
\hline 14 & 4.475 & moroba & $11: 07: 49$ & 7,8 & 13 & 49,18 & Boa & 43,33 \\
\hline 15 & 3.519 & moroba & $11: 44: 44$ & 6,5 & 6 & 45,72 & Boa & 37,67 \\
\hline 16 & 4.173 & reta & $12: 13: 53$ & 8 & 7,5 & 55,86 & Exc. & 35,11 \\
\hline 17 & 3.070 & moroba & $11: 04: 41$ & 8 & 7 & 53,28 & Exc. & $\mathbf{3 7 , 8 1}$ \\
\hline 18 & 4.395 & reta & $11: 06: 59$ & 7 & 10 & 44,71 & Boa & 39,58 \\
\hline 19 & 3.765 & moroba & $12: 06: 34$ & 7,5 & 8 & 42,65 & Boa & 37,19 \\
\hline 20 & 3.573 & reta & $11: 45: 34$ & 9 & 10 & 53,07 & Exc. & 36,75 \\
\hline 21 & 3.865 & reta & $10: 29: 38$ & 8,7 & 8 & 51,83 & Boa & 39,16 \\
\hline 22 & 4.086 & moroba & $09: 57,00$ & 6,3 & 7 & 68,66 & Exc. & 35,61 \\
\hline Média & $3.517,95$ & & 11:06 & 7,3 & 8,90 & 56,65 & Exc. & 36,62 \\
\hline
\end{tabular}

Fonte: Dados primários. 
Os dados apresentados na tabela 3 indicam que os trabalhadores cortaram em média 7,3 toneladas de cana, ingeriram uma média 8,9 litros de água, em jornadas de trabalho médias, se considerarmos com o momento de deslocamento no ônibus, de 11 horas. As informações referentes ao quantum de cana cortada e à hidratação foram concedidas pelos canavieiros após a jornada de trabalho.

O gasto calórico médio, estimado pelo monitor de frequência cardíaca, foi de 3.517,95 kgcal. A pesquisa de Silva Neta (2009, p. 60 ), que contou com uma amostra de 150 cortadores de cana dos canaviais paulistas, estimou um gasto calórico médio de 3,577 kcal diário, número muito próximo ao que estimamos.

Por causa de problemas na ativação do GPS do monitor de frequência, conseguimos acompanhar a distância percorrida de apenas 9 trabalhadores. A média de distância caminhada foi de 7,1 quilômetros, sendo que alguns desses caminharam até mais de 10 quilômetros durante um dia de trabalho.

Acerca da carga cardiovascular, os dados demonstram que a CCV do trabalhador " 5 ", no corte de cana crua, foi de 42,5\% (quase $10 \%$ acima do limite) para cortar 4,5 toneladas. O gasto calórico desse trabalhador atingiu o impressionante número de 5.103 kgcal. Para se ter uma ideia do que representa esse gasto calórico, basta citar que segundo McArdle et al (1999, Apud Ferreira et alli 2001) a média do gasto energético dos ciclistas de ponta durante o Tour de France é de 6.500kcal/ dia. Ainda no que tange à colheita de cana crua, os trabalhadores nos relatam que, nessa forma de colheita, o calor torna-se mais intenso.

Também é possível notar que o limite de carga cardiovascular foi ultrapassado tanto pelos 5 trabalhadores com aptidão cardiorrespiratória avaliada como boa, quanto por 13 dos 17 que apresentaram uma aptidão cardiorrespiratória excelente. Isso nos leva a concluir que, independentemente do condicionamento físico do canavieiro, esse trabalho é altamente extenuante.

Os dados da avaliação física revelam uma expressiva mudança corpórea para um período de tempo tão diminuto (do início ao fim da safra): a média do percentual de gordura baixou de $16,01 \%$ para 13,44\%, mas, se nos detivermos apenas nos números, a dor, que 
acompanha essas transformações, permanece invisível, permanece não dita. Segundo Carvalho e Pastre (2008 apud Nogueira, 2013), que analisaram o afastamento de trabalhadores canavieiros em Lucélia/ SP, dentre as principais causas de desligamento no corte da cana, foram encontrados os distúrbios musculoesqueléticos, que costumam acarretar fortes dores. Para a identificação desses distúrbios, utilizamos a versão brasileira do Nordic Musculoskeletal Questionnaire (Questionário Nórdico de Sintomas Osteomusculares), desenvolvido com o intuito de padronizar relatos de sintomas osteomusculares e, dessa forma, contribuir para comparação dos resultados. Segundo Pinheiro, Troccoli e Carvalho (2002), esse instrumento de pesquisa apresenta um alto índice de validade e recomendam sua utilização como medida de morbidade osteomuscular.

Ao todo, 33 trabalhadores canavieiros, participantes da primeira etapa das avaliações físicas, responderam o questionário que consiste em perguntas simples e diretas sobre a autopercepção da dor, desconforto ou dormência em partes do corpo durante os últimos 12 meses. Abaixo, segue a tabela 4 com alguns dos dados levantados: 
Tabela 4 - Resultados da aplicação do Questionário Nórdico de Sintomas

Osteomusculares: principais partes do corpo comprometidas

\begin{tabular}{|c|c|c|c|c|c|}
\hline Cortadores & Lombar & $\begin{array}{l}\text { Punho } \\
\text { direito }\end{array}$ & $\begin{array}{l}\text { Punho } \\
\text { esquerdo }\end{array}$ & $\begin{array}{l}\text { Ombro } \\
\text { direito }\end{array}$ & $\begin{array}{l}\text { Ombro } \\
\text { esquerdo }\end{array}$ \\
\hline 1 & $X$ & & $\mathrm{X}$ & & $\mathrm{X}$ \\
\hline 2 & $X$ & $X$ & & & $X$ \\
\hline 3 & $\mathrm{X}$ & $\mathrm{X}$ & & $\mathrm{X}$ & \\
\hline 4 & $\mathrm{X}$ & $\mathrm{X}$ & & & \\
\hline 5 & $\mathrm{X}$ & $\mathrm{X}$ & & & $\mathrm{X}$ \\
\hline 6 & & $\mathrm{X}$ & & & \\
\hline 7 & & & & & \\
\hline 8 & $\mathrm{X}$ & $X$ & & & $\mathrm{X}$ \\
\hline 9 & $\mathrm{X}$ & $\mathrm{X}$ & & & $\mathrm{X}$ \\
\hline 10 & $\mathrm{X}$ & & & $\mathrm{X}$ & \\
\hline 11 & $X$ & $\mathrm{X}$ & $\mathrm{X}$ & $X$ & $\mathrm{X}$ \\
\hline 12 & $\bar{x}$ & $\bar{X}$ & & & \\
\hline 13 & $\mathrm{X}$ & $\mathrm{X}$ & & & \\
\hline 14 & $\mathrm{X}$ & $\mathrm{X}$ & & & $\mathrm{X}$ \\
\hline 15 & $X$ & $X$ & & & $X$ \\
\hline 16 & & $X$ & & & \\
\hline 17 & $X$ & & & & \\
\hline 18 & $\mathrm{X}$ & $\mathrm{X}$ & & & $\mathrm{X}$ \\
\hline 19 & $X$ & & & & \\
\hline 20 & $\mathrm{X}$ & & & & $\mathrm{X}$ \\
\hline 21 & $X$ & $\mathrm{X}$ & & $X$ & \\
\hline 22 & $\mathrm{X}$ & & $\mathrm{X}$ & $\mathrm{X}$ & \\
\hline 23 & $X$ & $X$ & & & \\
\hline 24 & & $\mathrm{X}$ & & & \\
\hline 25 & $X$ & $X$ & & & \\
\hline 26 & $X$ & & & $\mathrm{X}$ & \\
\hline 27 & $\mathrm{X}$ & $\mathrm{X}$ & & & \\
\hline 28 & $\mathrm{X}$ & & & & \\
\hline 29 & $\mathrm{X}$ & & $\mathrm{X}$ & & \\
\hline 30 & $X$ & & & & \\
\hline 31 & $X$ & $\mathrm{X}$ & & & \\
\hline 32 & $\mathrm{X}$ & $\mathrm{X}$ & $\mathrm{X}$ & & \\
\hline 33 & $\mathrm{X}$ & $\mathrm{X}$ & & & \\
\hline $\begin{array}{c}\text { Média em } \\
\%\end{array}$ & & 66,67 & $15,15 \%$ & 18,18 & 30,30 \\
\hline
\end{tabular}

Fonte: Dados primários.

Os dados levantados demonstram prevalência de dor na região lombar, punhos e ombros. Também foi detectada incidência de dores em outras partes do corpo, mas não com números tão expressivos quanto nas regiões supracitadas.

Chama a atenção a elevada porcentagem de trabalhadores 
que sentem dor, desconforto ou dormência na região lombar. Os problemas nessa região afetam $87,88 \%$ dos trabalhadores que responderam o questionário - algo que corrobora os relatos colhidos durante a pesquisa de campo e com os achados de Nogueira (2013). Para se ter uma ideia da gravidade desse número, Ferreira (et al, 2011), em pesquisa que avaliou 972 adultos residentes na área urbana do município de Pelotas/RS, com idade entre 20 e 69 anos, conclui, mediante aplicação de questionário, que $40 \%$ das pessoas entrevistadas sentiram dor ou desconforto na região lombar nos últimos 12 meses - aproximadamente metade da incidência que encontramos nos trabalhadores canavieiros com idade entre 20 e 50 anos.

$\mathrm{O}$ alto índice de trabalhadores com dores nos punhos também merece destaque. Os dados sugerem que existe maior tendência de lesões e distúrbios no punho do membro dominante, responsável por golpear com o facão $(66,67 \%$ no punho direito e $15,55 \%$ no esquer$\left.\mathrm{do}^{16}\right)$. Esse padrão se repete no caso das dores no ombro, sendo que de modo inverso, pois os dados revelaram prevalência de dores no ombro responsável pelo movimento de abraçar a cana $(30,30 \%$ no ombro esquerdo e $18.18 \%$ no direito).

Além disso, cabe sublinhar a situação do trabalhador "11", que sentia dores em diversas partes do corpo. Para não perder o emprego, ele continuava trabalhando por meio de uso de automedicação. Queixou-se de dores crônicas, que estão se agravando com o passar das safras. Dores que aumentam a cada jornada, tonelada, golpe de facão, como se o corpo afirmasse: “Chega! Basta!”. Mas, se as dores o fizerem desacelerar, se elas o impedirem de continuar cortando sete toneladas de cana, ele não será contratado na safra seguinte.

A dissertação de Nogueira (2013) analisou a situação dos cortadores de cana que foram diagnosticados com Doenças Osteomusculares Relacionadas ao Trabalho (Dort) e que passaram pelo tratamento fisioterapêutico durante os anos de 2006 a 2007, em Rubiataba/GO. Foram identificados ao todo 112 prontuários, e localizados, após cinco anos, 36 trabalhadores que consentiram participar da pesquisa, o restante não foi localizado (muitos por causa da migra-

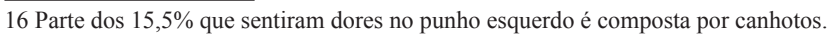


ção) e três cometeram suicídio - a autora sustenta que a doença osteomuscular, o afastamento do trabalho, e a diminuição da renda que já era ínfima, são fatores importantes para compreender as possíveis causas dos suicídios. Dos 36 trabalhadores localizados, 50\% permaneceram afastados por dois meses, 39\% por dois a seis meses e, somente, $11 \%$ foram afastados por mais de seis meses. Considerando o total da amostra de trabalhadores com Dort, somente 16,66\% continuaram no corte da cana, e apenas 5 trabalhadores conseguiram se aposentar, sendo 3 por invalidez.

Além do "saque lento da vida" (Lourenço, 2013) - como as Dort, negadas rotineiramente pelos laudos das Perícias Médicas do INSS -, uma pessoa com uma cardiopatia grave, se for submetida aos índices extremos de carga vascular demonstrados nesta pesquisa, sofre grande risco de morte súbita ${ }^{17}$.

Entrevistamos o médico de uma usina localizada na região dos tabuleiros de São Miguel dos Campos e indagamos-lhe sobre os critérios médicos adotados para empregar os cortadores de cana. Ele nos disse que existem "critérios físicos: avaliação para verificar se o trabalhador tem problemas posturais e de coluna" e que faz "uma avaliação abrangente para saber qual é a situação desse trabalhador". Todavia o mesmo não especificou como seria essa avaliação abrangente.

Decidimos investigar, perguntando diretamente aos cortadores de cana contratados pela usina em que o médico trabalha:

Pesquisador: Qual é o exame de rotina para entrar no emprego? Para ser admitido?

Entrevistado: Lá o doutor fica que nem você tá aí [sentado], e aqui ele tem uma mesa de ferro dessa altura aqui [apontando a altura]. Fica aquele bocado de homem olhando, tudo nu, 5 a 6 homens, o médico manda tirar a roupa. Aí ele fica assim de frente, fica aquele monte homem sentado em cima da banca. Tem uma maromba aqui, uma marombinha deste tamanho assim, de ferro. Aí vai descendo de um em um, aí pega na maromba, e levanta, depois bota aqui. Ele [o médico] diz "bote no chão"! Aí o cara vai, devagarzinho, e bota lá.

17 Conforme relato do médico cardiologista Roberto de Gusmão Verçoza, colaborador fundamental da pesquisa. 
P: Sabe quantos quilos tem essa maromba?

E: É... acho que é de $5 \mathrm{~kg}$. Porque é para ver se o pessoal tem hérnia. [..] É de $13 \mathrm{~kg}$. Aí pronto, depois vai vestir a roupa. Dali já passou. Não bota um aparelho, não bota nada.

P: Só é isso o exame?

E: Só é esse o exame!

P: E o coração?

E: A pressão já tem outra mulher lá para tirar a pressão.

P: Esses são os dois exames de entrada?

E: É, são esses dois exames, da maromba e a pressão.

P: Na entrada e na saída é o mesmo exame?

E: Para sair não tem negócio de exame não. É só chegar, entregou a carteira, assinou, pronto!

P: E o médico pergunta o que no exame? Ele pergunta o que na entrada? E: Na entrada ele só faz dizer assim: "ah rapaz, você é aquele 'cabra' que eu vi ano passado". Aí pronto, já passou.

P: Não faz exame nenhum? Não pergunta o que é vocês estão sentindo? E: Não, não pergunta não. Não pergunta o que é que o cara tem, não pergunta nada. Mas também se o cara for dizer, ele não entra. [risos] Se você for dizer como é que tá, ele não entra.

Esse relato, demonstra não somente a ausência de preocupação em avaliar se algum candidato ao emprego corre grave risco de morte súbita no corte da cana, ele revela, sobretudo, que os trabalhadores antes mesmo de serem contratados, já são tratados como coisas, como mera força de trabalho. A reificação, o sofrimento moral, precede o início da safra. A ausência do direito à privacidade, a fila de homens pelados aguardando ordens, faz-nos lembrar, mutatis mutandis, os relatos sobre os campos de concentração. No fim, o trabalhador revela o caráter hipócrita dessa farsa que ao, literalmente, despir os trabalhadores, põe a nu o caráter radicalmente reificante e hipócrita das relações que envolvem a usina e os trabalhadores: Não pergunta o que é que o cara tem, não pergunta nada. Mas também se o cara for dizer, ele não entra.

Em entrevista com um ex-cortador de cana, afastado por pro- 
blemas de saúde, perguntamos como ele havia descoberto sua doença cardíaca:

Pesquisador (P): E quando foi que você percebeu que tinha esse problema?

Entrevistado (E): Vim perceber esse problema de dois anos para cá. Estava cortando cana crua quando desmaiei de repente, então telefonaram para a usina e me levaram para o hospital de Junqueiro. O médico falou que era problema de coração. Fiz os exames e deu problema de coração.

P: Quais foram os exames que o senhor fez?

E: Fiz o eco, o eletro, o mapa, fiz todos.

Apesar desse quadro nefasto, marcado pelo risco de morte, no discurso público da gerência das usinas a preocupação com a saúde e segurança dos trabalhadores aparece como prioridade. Para sustentar tal imagem, eles não citam mudança na organização do trabalho, diminuição da largura dos “eitos gigantes”, fim da média mínima de toneladas diárias, redução da jornada de trabalho, abolição das fraudes que ampliam o rebaixamento salarial, tampouco a eliminação do salário por produção, não, nada disso. Para demonstrar a "sensibilidade" dos usineiros, são mencionados o uso dos EPIs (que pela legislação é obrigatório), a ginástica laboral (com aulas de alongamento ministradas pelo cabo (fiscal), que, por sua vez, baseia-se nas tentativas de imitar os movimentos retratados em fotocopias com desenhos do corpo humano) e o soro para hidratação oral e reposição de sais minerais (a fim de tentar diminuir os casos de "canguru" sem diminuir a carga de trabalho) ${ }^{18}$.

Ao analisar o tema em usinas do interior paulista, Scopinho chegou à seguinte conclusão (2003, p.261):

[...] Apesar de as empresas terem renovado seus discursos e prá-

18 Neta (2009), conclui que o alto gasto calórico requerido no corte da cana coloca os trabalhares em situação de risco, todavia, como alternativa ela não propôs redução da intensidade do trabalho, mas sim soro repositor de eletrólitos associado a complemento calórico. 
ticas de gestão introduzindo o ideário de qualidade total, a saúde do trabalhador ainda é tratada, predominantemente, como um fator de produção essencial. A política empresarial nessa área está voltada para o marketing social e as práticas restringem-se, quando muito, ao cumprimento da legislação. A saúde do trabalhador tem importância na medida em que a ocorrência de acidentes e/ou de doenças, além de representar uma diminuição da produtividade e custos adicionais de produção, pode também prejudicar a imagem da empresa no mercado. O cuidado com a saúde e a segurança dos trabalhadores constitui um dos requisitos para as conquistas dos selos, das certificações e para a elaboração dos pactos sociais, hoje tão necessários para romper as medidas protecionistas e facilitar a colocação de produtos no mercado, principalmente o internacional.

Em suma, a análise da política e das práticas em saúde e segurança no trabalho nesse setor a partir da experiência do Comando revelou que é grande a preocupação empresarial com a qualidade dos produtos, mas o mesmo não pode ser dito em relação à qualidade da vida dos trabalhadores.

Na perspectiva do capital agroindustrial canavieiro, a temática da saúde do trabalhador é preocupante, somente, quando ela pode afetar a saúde financeira da empresa. Enquanto o "canguru" continuar desconhecido fora dos eitos, enquanto as mortes súbitas forem consideradas uma fatalidade supostamente proveniente da predisposição de um corpo biológico frágil, enquanto os trabalhadores com Dort permanecerem sendo substituídos pelos mais jovens expropriados da terra, a pauta da saúde continuará como prioridade somente para o departamento de marketing das usinas - no sentido de tentar promover um ilusionismo.

Os dados levantados ao longo desta pesquisa vão na contramão da imagem criada por esses departamentos de marketing - que costumam mencionar certificações e selos para, supostamente, atestar compromisso ambiental e social. O monitoramento da frequência cardíaca dos cortadores de cana ao longo da jornada de trabalho (que, se considerarmos a partir do momento que sobem no ônibus até o retorno para 
casa, dura em média 11 horas!), revelou a superação do limite de risco de carga cardiovascular estabelecido pela literatura (Rodegers,1986; Lambers, et al, 1994), indicando que esse dispêndio de energia extremo (atingindo média de 36,68\% de CCV!) acarreta desgaste prematuro das energias "físicas e espirituais" do trabalhador. Esse altíssimo nível de esforço, realizado em calor inimaginável e com movimentos repetitivos em posições flexionadas, resulta em gasto calórico médio diário de 3.517,95 kgcal, ingestão de 8,9 litros de água e fortes dores no corpo e na alma (mais de $80 \%$ dos trabalhadores avaliados convivem com dores na coluna e nos punhos! $\left.!^{19}\right)$.

\section{A SUPEREXPLORAÇÃO E O DESGASTE PREMATURO DAS ENERGIAS VITAIS}

Parece-nos que a categoria superexploração, cunhada por Marini ao analisar o padrão de acumulação das economias dependentes à luz da teoria marxiana, é substancialmente relevante para compreensão da relação entre trabalho e adoecimento no corte manual da cana:

Pois bem, os três mecanismos identificados - a intensificação do trabalho, a prolongação da jornada de trabalho e a expropriação de parte do trabalho necessário ao operário para repor sua força de trabalho - configuram um modo de produção fundado exclusivamente na maior exploração do trabalhador, e não no desenvolvimento de sua capacidade produtiva. [...]

Além disso, importa assinalar que, nos três mecanismos considerados, a característica essencial está dada pelo fato de que são negadas ao trabalhador as condições necessárias para repor o desgaste de sua força de trabalho: nos dois primeiros casos, porque lhe é obrigado um dispêndio de força de trabalho superior ao que deveria proporcionar normalmente, provocando assim seu esgotamento prematuro; no último, porque lhe é retirada inclusive a possibilidade de

19 De acordo com os dados levantados pela aplicação do Questionário Nórdico de Doenças Osteomusculares. 
consumo do estritamente indispensável para conservar sua força de trabalho em estado normal. Em termos capitalistas, esses mecanismos (que ademais podem se apresentar, e normalmente se apresentam, de forma combinada) significam que o trabalho é remunerado abaixo de seu valor e correspondem, portanto, a uma superexploração do trabalho (Marini, 2005, p. 156 e 157).

A elevação do grau de exploração da força de trabalho pela intensificação e prolongamento da jornada de trabalho é prática trivial na agroindústria canavieira. Mas qual é o significado da expropriação de parte do trabalho necessário ao trabalhador? O que significa afirmar que na superexploração o trabalho é remunerado abaixo de seu valor?

Para elucidar tais questões, recorreremos às observações de Jaime Osório (2009, p. 176, 177):

$\mathrm{Na}$ análise feita por Marx sobre o valor da força de trabalho, encontram-se presentes duas dimensões: de um lado o valor diário, de outro, o valor total. Este último considera o tempo total de vida útil do trabalhador ou total de dias que o possuidor da força de trabalho pode vender a sua mercadoria no mercado em boas condições, além dos anos de vida que não participará da produção (ou anos de aposentadoria).

É o valor total da força de trabalho que determina o seu valor diário. A isso Marx alude quando indica que "o valor de um dia de força de trabalho é calculado [...] sobre a sua duração normal média ou sobre $a$ duração normal de vida de um operário e sobre o desgaste normal médio [...]”.

Então, o valor diário da força de trabalho deve ser calculado considerando um determinado tempo de vida útil dos trabalhadores e de vida média total, de acordo com as condições existentes na época. Os avanços na medicina social, por exemplo, permitem elevar a expectativa de vida, razão por que o tempo da vida produtiva e o de vida total também se prolongaram. Isso implica que, se atualmente um indivíduo pode trabalhar por trinta anos sob condições normais, o pagamento diário da força de trabalho deve permitir a ele se repro- 
duzir de tal forma que possa apresentar-se no mercado de trabalho durante trinta anos e viver por um determinado números de anos de aposentadoria em condições normais, e não menos.

Um salário insuficiente ou um processo de trabalho com superdesgaste (seja pelo prolongamento da jornada de trabalho, seja pela intensificação do trabalho), que encurte o tempo de vida útil total e de vida total, constitui um caso no qual o capital está se apropriando hoje dos anos futuros de trabalho e de vida. Definitivamente, estamos diante de processos de superexploração, na medida em que se viola o valor da força de trabalho.

Transcrevemos essa longa citação, porque ela apresenta de modo didático pressupostos básicos do valor da força de trabalho. Se a superexploração é definida pela violação desse valor, temos que esclarecer do que ele é composto. O primeiro ponto fundamental diz respeito ao fato de ser o valor total da força de trabalho que determina o valor diário da mesma. Mas o que determina o valor total? Como salienta Osório: "determinado tempo de vida útil dos trabalhadores e de vida média total, de acordo com as condições existentes na época". Ora, se a intensificação do trabalho e o prolongamento da jornada encurtam o tempo de vida útil e o tempo de vida total, logo o capital está "se apropriando hoje dos anos futuros de trabalho e de vida". Como distinguiu Marx (1985, p. 189): "A utilização da minha força de trabalho e a espoliação dela são duas coisas totalmente diferentes".

Vimos como o capital agroindustrial canavieiro se apropria hoje dos anos futuros do cortador de cana por meio dos mecanismos de intensificação e extensão do trabalho - podendo desencadear até morte súbita. Mas, além desses dois mecanismos supracitados, existe ainda o terceiro: a expropriação de parte do trabalho necessário ao assalariado. Esse último mecanismo, que se dá de modo combinado com os primeiros, está presente nas fraudes das medições e pesagens de cana cortada, na ausência de controles sobre os descontos nos holerites, "no pulo da vara" do cabo, que tem como outro lado da mesma moeda "o pulo do "canguru" e o rebaixamento salarial da remunera- 
ção que já seria baixa mesmo sem fraude. A usina não abocanha somente o camuflado trabalho excedente, ela abocanha o trabalho necessário com a mesma indiferença de uma fornalha que queima bagaço.

Essa forma de exploração-dominação, denominada por Marini como superexploração, pode parecer, para alguns, como resquício de formas primitivas de acumulação, como uma espécie de arcaísmo anacrônico. Para evitar esse tipo de confusão, Marini esclarece de modo preciso:

O que importa assinalar aqui, em primeiro lugar, é que a superexploração não corresponde a uma sobrevivência de modos primitivos de acumulação do capital, mas que é inerente a esta e cresce correlativamente ao desenvolvimento da força produtiva do trabalho. Supor o contrário equivale a admitir que o capitalismo, à medida que se aproxima de seu modelo puro, converte-se em um sistema cada vez menos explorador e logra reunir as condições para solucionar indefinidamente as contradições internas (Marini, 2005b, p. 192).

Ainda no que tange a apropriação de parte do trabalho necessário ao trabalhador, os dados levantados revelam que o dispêndio de energia (CCV) encontrado no trabalho dos canaviais alagoanos foi muito semelhante ao dos eitos paulistas (Laat, 2010), o mesmo pode ser afirmado em relação ao gasto calórico (Neta, 2009) e quantidade de água ingerida (Alves, 2006), todavia a discrepância da média de tonelada cortada nos chamou a atenção. Enquanto Laat (2010, p. 153) encontrou uma produção média de 12,77 toneladas de cana cortada, ao acompanhar 36 trabalhadores em um talhão de cana deitada (tipo rolo), nós detectamos uma média de 7,3 toneladas em talhões nas terras planas dos tabuleiros e com diversos tipos de cana. Esse fator fortalece a tese de que, em decorrência dos "eitos gigantes" (mais largos) e das fraudes colossais, a tonelada de cana em Alagoas tenha mais trabalho não pago do que a paulista - que já apresenta níveis absurdos. Desse modo, a maior média encontrada nos canaviais paulistas não representa necessariamente mais trabalho corporificado, mas talvez menor largura de eito e menor margem de fraude no cálculo da tonelada. 


\section{A LUTA PELO RECONHECIMENTO DO NEXO CAUSAL}

Ainda é preciso mencionar que o trabalhador sai do canavial, mas o canavial não sai do trabalhador. Ele não se reconhece naqueles montes de canas cortadas, mas se reconhece a cana em seu rosto sujo de fuligem, nas dores de madrugada, na ausência de energia para acariciar a esposa, que, na maioria esmagadora dos casos, lava a roupa melada de suor e poeira. A cana se faz presente até na ausência do trabalhador, que não pôde ir à festa porque estava esgotado, e quando tinha disposição para levar a família à praia, não tinha dinheiro para pagar o transporte e a refeição - "é preciso pensar na entressafra, como iremos sobreviver?". Até a ausência dele no canavial, por não conseguir mais atingir a média mínima diária.

Todavia, existe uma luta incessante contra o estranhamento vivenciado no trabalho. A reificação do trabalhador não é total. Além da reação mediante greves e paralisações - nos canaviais paulistas e alagoanos pululam ações desse tipo -, ocorrem ainda as "resistências miúdas" (Silva, 2008) do cotidiano, que acontecem de modo oculto, por trás do verde monocromático do canavial. O etanol e o açúcar que aparecem nas prateleiras e nas bombas de combustível não escondem apenas as relações sociais que os criam enquanto mercadorias, mas encobrem ainda as lutas que contestam as formas brutais de estranhamento, escondem os homens e as mulheres que continuam "estranhando o trabalho estranhado", e "desestranhando" a possibilidade de sua superação.

Como convém recordar:

Os homens fazem sua própria história, mas não a fazem como querem; não a fazem sob circunstâncias de sua escolha e sim sob aquelas com que se defrontam diretamente, legadas e transmitidas pelo passado. A tradição de todas as gerações mortas oprime como um pesadelo o cérebro dos vivos (Marx, 2002, p. 21).

Em suma: o ser social é produto e produtor da realidade social e da história. Desse modo, não existe uma separação mecânica entre o mundo objetivo e o mundo subjetivo, ambos estão dialeticamente 
articulados. As possibilidades de atividade humana para modificar uma dada realidade social são determinadas pelos limites objetivos dessa mesma realidade. No entanto, as transformações não ocorrem por um movimento mecânico das forças produtivas, pois "as circunstâncias são precisamente modificadas pelos homens", por sua práxis. O ser humano é radicalmente histórico e social.

É a partir desses pressupostos que Thompson formula o conceito de experiência. Para o autor

Os homens e mulheres também retornam como sujeitos, dentro deste termo [experiência] - não como sujeitos autônomos, "indivíduos livres", mas como pessoas que experimentam suas situações e relações produtivas determinadas como necessidades e interesses e como antagonismos, e em seguida "tratam" essa experiência em sua consciência e sua cultura [...] das mais complexas maneiras [...] e em seguida (muitas vezes, mas nem sempre, através das estruturas de classe resultantes), agem, por sua vez, sobre a situação determinada (Thompson, 1981, p.182, grifos nossos).

Conforme sublinha Silva (2009b, p. 108), afirmar "que a experiência é resultante da imbricação da ação dos sujeitos e das estruturas sociais existentes é o mesmo que admitir que as circunstâncias fazem os homens, assim como os homens fazem as circunstâncias." Para a autora, no conceito proposto por Thompson, a experiência é tratada pela consciência e pela cultura dos homens e mulheres, "que diz respeito à reelaboração, ressignificação de sentimentos, maneiras de pensar, de ser e de agir a partir do mundo social em que se vive" (Idem). $\mathrm{O}$ que nos interessa reter do conceito de experiência é que, nele, a resistência dos canavieiros pode ser compreendida como um processo presente no cotidiano e inserida em relações sociais determinadas.

Os canavieiros resistem, sabotando os padrões técnicos do corte da cana de modo dissimulado, tocando fogo nos canaviais, plantando macaxeira numa "boca de grota" (Verçoza; Silva, 2012). Como diria o cabo de uma usina: "Em toda turma tem um trabalhador desenquadrado". E eles também resistem de modo coletivo, ao 
organizar greve, na maior parte das vezes à revelia do sindicato, ao bloquear uma rodovia para reivindicar o pagamento de salários atrasados, dentre outras formas de luta (Verçoza; Silva, 2012).

Todavia, nessas ações dificilmente a temática da saúde surge à tona. Em geral, somente é considerada importante, quando o trabalhador já se encontra doente e, nesse caso, o terreno da batalha costuma ficar restrito ao INSS e ao judiciário, espaços que tendem a individualizar a questão e descaracterizar a causa do adoecimento. A luta pelo reconhecimento do nexo causal se faz urgente, e não tem como essa luta ser vitoriosa sem mudanças profundas na forma de trabalho que gera o adoecimento. Caso não seja esse o norte da luta, estaremos condenados a lutar contra "os efeitos, mas, não contra a causa desses efeitos" (Marx, 1982, p. 184).

\section{6 À GUISA DE CONCLUSÃO}

A presente pesquisa revelou, por meio de uma metodologia que articulou a investigação sociológica aos instrumentos de pesquisa característicos da área de saúde, que o trabalho no corte da cana, além de gerar o adoecimento, pode levar à morte. Esperemos que esta investigação contribua para o surgimento de novos estudos com semelhante esforço interdisciplinar, pois, na temática do trabalho rural, predominam estudos sociológicos que citam dados de pesquisas da área da saúde, e estudos da área da saúde que citam pesquisas sociológicas. Preencher essa lacuna dos estudos rurais e dos estudos da saúde foi um dos objetivos desta pesquisa. Para além da contribuição no universo acadêmico, temos esperança de que pesquisas com esse caráter possam fortalecer a luta dos trabalhadores canavieiros, pois, afinal, os dados levantados apontam que, no caso do corte da cana, não se trata somente de lutar por uma vida cheia de sentido dentro e fora do trabalho, infelizmente ainda é necessário lutar por algo ainda mais básico: pelo direito de não morrer em decorrência do excesso de trabalho. A luta pelo reconhecimento do nexo causal se faz urgente, e não tem como essa luta ser vitoriosa sem mudanças profundas na forma de trabalho que gera o adoecimento. 


\section{REFERÊNCIAS}

ADORNO, T.; HORKHEIMER, M. A Dialética do Esclarecimento. Rio de Janeiro, Jorge Zahar, 1985.

AGUIAR, R. A. de et al. The Effects of Different Training Backgrounds on VO2 Responses to All-Out and Supramaximal Constant-Velocity Running Bouts. PLoS ONE, 10(8): e0133785, jornal, 2015.

ALVES, F. J. da C. Por que morrem os cortadores de cana? 2006. Disponível em: <http://www.scielo.br/pdf/sausoc/v15n3/08.pdf>. Acesso em: 2 jun. 2008.

- Migração de trabalhadores rurais do Maranhão e Piauí para o corte da cana em São Paulo. In: NOVAES, J. R.; ALVES, F. (Org.). Migrantes: trabalho e trabalhadores no complexo agroindustrial canavieiro (os heróis do agronegócio brasileiro). São Carlos: EdUFSCar, 2007.

ALBUQUERQUE, C. F. de. Casa, Cana e Poder. Maceió: EDUFAL, 2009.

ALESSI, N. P.; NAVARRO, V. L. Saúde e trabalho rural: o caso dos trabalhadores dacultura canavieira na região de Ribeirão Preto, São Paulo, Brasil. Cadernos de Saúde Pública, Rio de Janeiro, v. 13, supl. 2, p.111-121, 1997.

APUD, E. Guidelines on ergonomics study in forestry. Genebra: ILO, 1989.

BARBOSA, C. M. G. Avaliação cardiovascular e respiratória em um grupo de trabalhadores cortadores de cana-de-açúcar queimada no Estado de São Paulo. 2010. Tese (Doutorado em Ciências) Programa de Pós-graduação em Pneumologia, Faculdade de Medicina da Universidade de São Paulo, São Paulo.

BRASIL. Ministério do Trabalho e Emprego. Perfil dos Acidentes de Trabalho no Estado de Alagoas. 2013. Disponível em: <file://C:/Users/L\%C3\%BAcio/Downloads/Estudo\%20dos\%20 Acidentes\%20no\%20Setor\%20Sucroalcooleiro\%202012\%20 ENIT\%20(1).pdf >. Acesso em: 20 jun.2015.

CARVALHO, C. P. de O. Análise da reestruturação produtiva da agroindústria sucroalcooleira alagoana. Maceió: EDUFAL, 2009.

COMPANHIA NACIONAL DE ABASTECIMENTO. Acompanhamento da safra brasileira de cana-de-açúcar. Safra 2015/16, n.4, levantamento, 2016. 
. 2016. Disponível em: <http://www.conab.gov.br>. Acesso em: 3 dez. 2016.

DAGNINO, E. Construção democrática, neoliberalismo e participação: os dilemas da confluência perversa. Política \& Sociedade, n. 5, p.139164, out. 2004.

DEPARTAMENTO INTERSINDICAL DE ESTUDOS E PESQUISAS DE SAÚDE E DOS AMBIENTES DE TRABALHO. Insalubridade: morte lenta no trabalho. São Paulo: Aboré, 1989.

EDHOLM, O. G. Biologia do trabalho. Porto: Inova, 1968.

FERREIRA, G. D. et al. Prevalência de dor nas costas e fatores associados em adultos do sul do Brasil: estudo de base populacional. Revista Brasileira de Fisiotererapia, v. 15, n.1, pp. 31-36, 2011.

GONZAGA, M. C. O uso dos equipamentos individuais de proteção e das ferramentas de trabalho no corte manual da cana - de - açúcar. São Paulo: FUNDACENTRO, 2002.

GRANDJEAN, E. Manual de Ergonomia: adaptando o Trabalho ao Homem. Porto Alegre: Bookman, 1998

GRANEMANN, S. Previdência social: Da Comuna de Paris aos (falsos) privilégios dos trabalhadores. In: NAVARRO, Vera; LOURENÇO, Edvânia. (Org.). O avesso do trabalho - III. São Paulo: Outras Expressões, 2013.

LAAT, E. F. de. Trabalho e risco no corte manual de cana-de-açúcar: a maratona perigosa nos canaviais. 2010. Tese (Doutorado) Programa de Pós-graduação em Engenharia de Produção da Universidade Metodista de Piracicaba, Santa Bárbara d' Oeste - SP, 2010.

LAMBERS, M. I.; CHEEVERS, E. J.; COOPOO, Y. Relationship between energy expenditure and productivity of sugar cane cutters and stackers. Occupational Medicine. v. 44, p.190-194, 1994.

LAURELL, A. C. A saúde-doença como processo social. In: NUNES, E. D. (Org.). Medicina social: aspectos históricos e teóricos. São Paulo, Ed. Global, 1983.

LAURELL, A. C.; NORIEGA, M. Processo de Produção e Saúde: trabalho e desgaste operário.São Paulo: Editora HUCITEC: 1989.

LIMA, C. Q. B.; GONZAGA, M. C. Análise de luvas de proteção usadas no corte manual da cana-de-açúcar. São Paulo: FUNDACENTRO, 2011. 
LOURENÇO, E. A. S. Alienação e agravos à saúde dos trabalhadores no setor sucroenergético. In: LOURENÇO, E. Â. de S., NAVARRO, V. L. O avesso do trabalho III: Saúde do trabalhador e questões contemporâneas. São Paulo: Outras Expressões, 2013.

MARX, K. Salário, preço e lucro. In: Para a crítica da economia política; Salário, preço e lucro; $O$ rendimento e suas fontes: a economia vulgar. São Paulo: Abril Cultural, 1982.

. O Capital: crítica da economia política.Tomo 1. São Paulo: Nova Cultural, 1985.

. O 18 Brumário e Cartas a Kugelmann. Rio de Janeiro: Paz e Terra, 2002.

- Manuscritos econômico-filosóficos. São Paulo: Boitempo Editorial, 2004.

MARINI, R. M. Dialética da dependência. In: STEDILE, J. P.; TRANSPADINI, R. (Org.). Ruy Mauro Marini vida e obra. São Paulo: Expressão Popular, 2005.

Sobre a Dialética da dependência. In: STEDILE, J. P.; TRANSPADINI, R. (Org.). Ruy Mauro Marini vida e obra São Paulo: Expressão Popular, 2005b.

MELlO, P. D. de A. Cana-de-açúcar e reestruturação produtiva: ação sindical e os movimentos sociais rurais em Alagoas a partir de 1985. 2002. Tese (Doutorado). Programa de Pós-Graduação em Sociologia da Universidade Federal de Pernambuco, Recife, 2002.

MENEGHELO, R. S. et al. III Diretrizes da Sociedade Brasileira de Cardiologia sobre teste ergométrico. Arq. Bras. Cardiol., São Paulo, v. 95, n. 5, supl. 1, p.1-26, 2010.

NETA, M. de L. da S. Perfil nutricional e de saúde de cortadores de cana nordestinos migrantes no sudeste do Brasil. 2009. Dissertação (Mestrado) Programa de Pós-graduação em Nutrição da Universidade Federal de Alagoas, Maceió, 2009.

NOGUEIRA, S. M. Perfil socioeconômico de cortadores de cana-de-açúcar que desenvolveram distúrbios osteomusculares relacionados ao trabalho (DORT) Rubiataba-Goiás. 2013. Dissertação (Mestrado) Programa de Pós-Graduação em Ciências Ambientais e Saúde da Pontíficia Universidade Católica de Goiás, Goiânia, 2013. 
OSÓRIO, J. Dependência e superexploração. In: MARTINS, C. E.; VALENCIA, A. S. (Org.). A América Latina e os desafios da globalização: Ensaios dedicados a Ruy Mauro Marini. Rio de Janeiro: Ed. PUC- Rio; São Paulo: Boitempo Editorial, 2009.

PINHEIRO, F.; TRÓCCOLI, B.; CARVALHO, C. Validação do Questionário Nórdico de Sintomas Osteomusculares como medida de morbidade. Rev. Saúde Pública, v. 36, n. 3, p.307-312, 2002.

PLANCHEREL, A. A.; QUEIROZ, A. S.; SANTOS, C. dos. O “canguru” no universo canavieiro alagoano: saúde e precarização do trabalho na agroindústria açucareira. Revista Rede de Estudos do Trabalho (RRET). 2010. Disponível em: <http://www.estudosdotrabalho. org/08RevistaRET7.pdf>. Acesso em: 10 jan. 2011.

RODGERS, S. Ergonomic design for people at work. New York: John Wiley \& Sons, 1986.

SANTOS, Adriano Pereira. Contradições do desenvolvimento capitalista no Brasil: as transformações do trabalhador rural em proletariado agrícola. In: SANT'ANA, R. S.; CARMO, O.; LOURENÇO, E. Â. (Org.). Questão Agrária e Saúde dos Trabalhadores: desafios para o século XXI. São Paulo: Cultura Acadêmica, 2011.

SANTOS, C. C. S. dos. A. (IN)Segurança Alimentar de Famílias de Trabalhadores Canavieiros em Alagoas. In: PLACHEREL, A. A.; BERTOLDO, E. (Org.). Trabalho e Capitalismo Contemporâneo. Maceió, AL: EDUFAL, 2011.

SCOPINHO, R. A. Vigiando a Vigilância: saúde e segurança no trabalho em tempos de qualidade total. São Paulo: Annablume, Fapesp, 2003.

SILVA, M. A. de M. Cortadores de Cana e os (Não) Direitos. Travessia: Revista do Migrante, Publicação CEM - Ano XXI, n. 61, p.26-36, 2008.

. A barbárie do i-mundo eitos dos canaviais. In: FACIOLI, I. (Org.). Vozes do eito. Guariba: Eco das Letras, 2009.

Assentamento Bela Vista, a peleja para ficar na terra. In: MARTINS, J. de S. (Org.). Travessia: a vivência da reforma agrária nos assentamentos. Porto Alegre: Editora da UFRGS, 2009b.

SILVA, M. A. de M.; VERÇOZA, L. V. de V.; BUENO, J. D. A imagem do etanol como 'desenvolvimento sustentável' e a (nova) morfologia do trabalho. Caderno CRH, UFBA, v. 26, p. 253-271, 2013. 
SILVA, M. A. de M.; BUENO, J. D.; VERÇOZA, L. V. de V. O trabalho à flor da pele: formas contemporâneas de estranhamento do trabalho nos canaviais e nos campos de flores. Cadernos Ceru, USP, v. 24, n.1, p. 13-37, 2013.

THOMPSON, E. P. A Miséria da Teoria ou um Planetário de Erros. Rio de Janeiro: Zahar Editores, 1981.

VERTHEIM, M. A. R.; GOMEZ, C. M. As armadilhas: bases discursivas da neuropsiquiatrização das LER. Ciênc. saúde coletiva, v.6, n. 2, p.457-470, 2001.

VERÇOZA, L. V. de; SILVA, M. A. de M. A resistência dos trabalhadores nos canaviais alagoanos. Agrária, São Paulo, v. 13, p.137-168, 2012.

WEIL, S. Experiência da vida de fábrica. In: BOSI, E. (Org). A condição operária e outros estudos sobre a opressão. Rio de Janeiro: Paz e Terra, 1999.

YABE, M. Mais rápido, mais alto, mais forte: a superexploração e a saúde dos "atletas olímpicos" dos canaviais alagoanos. 2013. Dissertação (Mestrado em Sociologia) Programa de Pós-graduação em Sociologia da Universidade Federal de Alagoas, Maceió.

Recebido:12/07/2016. Aprovação final:10/12/2016. 